Trata-se de uma manifestação do crescimento do Estado. O direito contratual regula fundamentalmente a atividade dos cidadãos, $\mathrm{e}$, por isso, verifica-se a tendência a restringíla, a lo penal, a criação de figuras delituosas, regula a atividade punitiva Estado. Em consequencia tende-se a ampliá-la, a despojá-la de entraves, a conferir-lhe mais livre jôgo.

O princípio de reserva deve continuar a proibir a analogia incriminadora. Feita esta restrição, garantidora da a analogia da dignidade da pessoa, a analogia constitui fonte do direito penal e, associada à equidade, constitui norma individualizadora, descobrindo as relações entre a abstração da lei e a concreção variável e específica do real.

\title{
ECONOMIA DIRIGIDA E DIREITO COMERCIAL *
}

\author{
HERNANI ESTRELLA
}

Catedrático de Direito Comercial.

1. - A economia liberal no Brasil. 2. - o comércio exterior brasileiro. 3 . - 0 mercado de consumo interno. 4. - As idéias de livre iniciativa e livre emprêsa na contextura do nosso direito comercial. 5. - Valorização artificial. 6. - Crescente intervencionismo econômico. 7. - Produção e circulação controladas. 8. - Estado empresário e competidor privilegiado. 9. - Intervenção corretiva ou supletiva e não supressiva. 10. - Inaptidão congênita do poder público para ser empresário. 11. - Posição do direito comercial face à economia dirigida. 12 . Comercialização do direito público. 13. - Submissão do Estado comerciante ao império do direito comercial.

1. - O Brasil se fez independente e viveu a maior parte de sua existência, sob o signo da chamada economia liberal. No largo período de mais de um século, que vai da Independência ao fim da primeira República, ou, mais precisamente, da Constituição de 1824 à de 1891, abrogada pelo golpe de estado de 1930, foram completamente livres em nosso país tôdas as atividades econômicas. Exceção feita da navegação de cabotagem, reservada aos nacionais por motivos óbvios e salvo, também, medidas de caráter aduaneiro, tendentes a estimular a indústria incipiente e propiciar renda ao tesouro, a posição do Estado era de vigilância e tutela.

Tôdas as formas de produção eram franqueadas, indistintamente, a nacionais e estrangeiros. $\mathrm{O}$ capital alienígena podia en trar livremente no país, aqui aplicar-se a qualqưer gênero de in- 
dústria e daqui retornar quando e como entendesse. Livre era a indivíduos ou associações planejar, instalar e explorar qualquer ramo de comércio, desde que lícito e não contrário aos bons costumes.

$\mathrm{Na}$ competição econômica, a que todos se podiam entregar, os únicos limites postos em lei assentavam em fundadas considerações de tutela à prudência e lealdade comerciais e repressão ao ilícito. $\mathrm{O}$ acesso ao mercado a todos se abria. Cada qual que o procurasse conquistar, segundo suas aptidões e a excelência dos produtos que pudesse oferecer. $\mathrm{O}$ Estado não tinha preferências nem monopólios. Produzia quem quisesse e pudesse. Tanto que respeitadas fossem normas de proteção à segurança, higiene e saúde, mais não se impunha ao industrial ou comerciante.

Contando, então, sòmente com o risco, que é inerente a todo empreendimento especulativo, o produtor ficava entregue à sua própria sorte. Tinha na esperança de lucro a contra-partida de eventual prejuizo. Se era bem sucedido, seus eram os proventos auferidos. A ordem jurídica lhe garantia o gôzo pacífico e a livre disponibilidade. Podia fazer ou deixar de fazer novas inversões, montar novas indústrias, empreender novos negócios.

Tudo isso era problema estranho ao poder público. Fôsse prudente e leal o agente econômico, mais não lhe pediam as leis. Mas, se caísse em insolvência, viesse a quebrar, o Estado, então, tomava-lhe contas. Haveria de justificar-se, perante a lei e seus credores, pelos padrões dos de sua classe. Moratória ou remissão de dividas sòmente os credores poderiam outorgar. Os contratos que celebrava e as obrigações que contraíra deviam, em princípio, ser rigorosamente cumpridos. A soberania do contrato não consentia mitigações de suas cláusulas, por mais onerosas que fôssem.

O grande princípio da liberdade implicava o da completa responsabilidade. As obrigacões convencionais tinham aquela por pressuposto e conduziam, necessàriamente, a esta última. Nessa idéia assentava a punição da falência, que seria havida como culposa ou fraudulenta, consoante para seu evento tivesse concorrido simples culpa ou dolo.

Tendo o gôsto pela aventura e a certeza de que de si mesmo, em máxima parte, dependia o êxito, o industrial ou comerciante se sentia estimulado a produzir mais e melhor.

Foi nesse clima benfazejo que se criou tôda a nossa riqueza. Todos os organismos econômicos e instituições que ainda possuimos devemos à tão malsinada economia liberal.

2. - Embora tendo como única fonte produtora de divisas exteriores a exportação de artigos primários e alguns poucos cultivados, mesmo assim podíamos importar tudo de que carecíamos e que representava, então, apreciável volume físico de mercadorias manufaturadas, pois a indústria nativa se mostrava insuficiente, assim em quantidade, como em qualidade. (1)

$O$ café, que era e ainda continua sendo, o elemento básico de nossas exportações, encontrava preco assaz compensador nos mercados europeus e americanos. Proporcionava-nos, assim, os recursos em divisas fortes de que necessitávamos. O cacau, a borracha, alguns subprodutos da pecuária e o algodão, embora de qualidade inferior, na época, ao de outras proveniências, tinham larga aceitação na Alemanha, principalmente, que era um de nossos maiores compradores.

Êsse país, além de consumidor, reexportava para mercados do Norte da Europa e até mesmo para a Rússia (antes do advento do comunismo) grandes quantidades de café, que nos adquiria. Graças a êsse intercâmbio, tínhamos um fluxo permanente e regular de utilidades exportáveis, em troca das muitas que adquiríamos.

A garantia de pleno emprêgo ao capital e à técnica estrangeiros permitiu o surto de grandes indústrias básicas, cuja instalação e mantença não nos fôra possível pela carência dos recursos necessários. Mercê disso, surgiram no país serviços imprescindíveis ao nosso progresso, confôrto e bem estar. Ferrovias, portos, canais, usinas elétricas, telefone, cabo submarino, transportes fluviais e urbanos e tantos outros foram criados, mantidos e explorados por entidades estrangeiras. (2)

Os portadores de seus títulos acionários e debenturiais, domiciliados no exterior, tinham a segurança da percepção de seus dividendos ou juros, que livremente saíam do país para seu pagamento. bens.

Livre era a quem quer entrar no país e dêle sair com seus

Satisfeitos os requisitos mínimos de regularidade, qualquer um podia importar donde quisesse e o que entendesse.

$\mathrm{O}$ comércio em tôdas as suas formas, inclusive o de câmbio manual e trajectício, não sofria maiores restrições além das já lembradas.

O preço de coisa, de serviço ou de dinheiro era aquêle ajustado pelas partes. Tão livre lhes era pactuá-lo, como obrigatório satisfazê-lo.

$\mathrm{Na}$ ordem econômica de então, cada qual respondia pelos próprios atos. A lei sòmente intervinha para proteção aos juridicamente incapazes, ou para reprimir o ilícito.

(1) - Como se sabe, foi a Grande Guerra de 1914 a 1918 que trouxe notável
impulso à indústria nacional, em razão sobretudo, das dificuldades de (2) - Cf. CAIO PRADO JUNIOR - História Econômica do Brasil, pg. 254 


\section{$-54-$}

3. - Assim se passavam as coisas no plano da economia de produção ou de mercado. Diferente não era, também, na de consumo. Tôdas as utilidades eram livremente adquiridas, segundo a capacidade de compra de cada qual. Os gêneros alimentícios e os mais imprescindíveis à satisfação de necessidades vitais eram fàcilmente encontráveis no comércio dito varejista ou retalhista, que os oferecia diretamente ao consumidor, levando-os, ordinàriamente, à moradia do freguês. Por seu turno, o comerciante a retalho podia livremente adquirir dos atacadistas ou de produtores todos os gêneros de seu comércio e, também livremente, fixar os preços de revenda. O problema de lucro ou perda era exclusivamente seu.

As chamadas indústrias domésticas ou caseiras, entregues ao labor da família, exercitavam-se sem entraves. Manteiga, vinho, doces, produtos da suinocultura, conservas, etc. constituiarn fonte de renda subsidiária, apreciável do colono, granjeiro e hortelão, que assim tinha compensada, por vêzes, as adversidades sobrevindas à produção principal. Tudo isso confluia para o mercado, aumentando a massa das trocas.

Nenhum embaraço fiscal ou burocrático se opunha a tão úteis iniciativas, que se vinham juntar às maiores, desenvolvidas pelas grandes emprêsas.

Também a pequena indústria transformadora ou de mero be neficiamento desfrutava as mesmas facilidades. Patente gratis para instalar e funcionar; isenção de tributos, nenhuma formalidade ad ministrativa a entorpecer-lhe os movimentos. Operários e artífices autônomos existiam em tôdas as cidades e povoados, executando obras ou serviços sob encomenda, ou para compradores eventuais.

A moeda estava razoàvelmente estabilizada no seu poder de compra. Era possível a previsão orçamentária, tanto para produtores, como para consumidores. A certeza na vigência da lè e na sua estabilidade permitiam formular cálculos para o futuro. Animava a poupança e propiciava iniciativas a longo prazo.

Vivia-se, enfim, na era ou no "Mundo da segurança", com? disse com muita propriedade Stefan Zweig.

4. - Nesse clima e sob o influxo dessas idéias, articulouse o código comercial brasileiro e desenvolveu-se a se o código comercial brasileiro e desenvolveu-se a
nossa ciência do direito comercial. Suas normas e seus princípios refletiam essa realidade econômica. Dela participavam como autores, apenas, os indivíduos e as entidades coletivas privadas. Longe estavam legislador e teoristas de pensar em que pudesse o Estado transmudar-se em mercador ou industrial. Por isso, tal hipótese estivera fora de suas cogitações. Sujeito do comércio eram sòmente aquelas pessoas.

Nesse pressuposto, cuidou-se de delimitar o objeto típico da disciplina. Não era difícil o enunciar. Tinha-se a noção histó rico-econômica do fenômeno. Revelara-se êle através do escambo, forma que se diferenciara da troca direta primitiva, não apenas quanto às pessoas intervenientes, senão também quanto ao motivo que o animava. Na simples permuta entre produtor e consumidor, o fim último da operação era a satisfação de necessidades de cada um dos permutantes. As coisas trocandas eram consideradas em função de sua utilidade imediata e individual. No comércio, ao contrário, as coisas eram encaradas em face de sua prestabilidade para a troca ulterior. Daqui a distinção técnica entre bem $M E R C A D O R I A$, distinção que não se funda na diversidade subs tancial, mas sim na diferente destinação (3).

Fazia-se a permuta direta, como meio de aquisição de bens imprescindiveis à vida, ao confôrto, ao bem estar. Exercia-se a mediação com finalidade especulativa, com o propósito ou causa lucrandi, como diziam os comercialistas clássicos.

Dessarte, na nocão de ato essencialmente comercial estava implícita a idéia de lucro. E quem o praticasse habitualmente, por profissão, comerciante seria. Assim, em primeiro plano, o direito mercantil se revelava a disciplina jurídica das relações advindas do exercício do comércio. Conceito econômico e jurídico eram coincidentes.

Disso resultou importantíssimo efeito, qual seja o de reputarem-se sempre onerosos os atos praticados no ou para exercício da mercancia. Por êsse prisma, puderam-se distinguir contratos, como o de mandato, depósito, fiança e outros, geralmente gratuitos no direito civil, e sempre remunerados no direito comercial.

Êsse critério veio permitir se estendesse à indústria o império da legislação mercantil, eis que foi ela entrevista, também, como forma de intromissão especulativa, concretizada através da função exercida pelo empresário no coordenar os fatores da produção no assumir os riscos.

Em razão da liberdade assegurada a nacionais e estrangeiros para exercer qualquer ramo de comércio ou indústria, o direito mercantil pátrio dizia-se liberal, internacionalista e universalista. Expandia-se e aperfeiçoava-se, mercê de usos e práticas trazidos de outras terras pelos de fora, que para aqui vinham e se lançavam no meneio dos negócios. Renovava-se e afeiçoava-se às novas e sempre crescentes exigências do tráfico. Onde a preceituacão positiva era omissa, ou já obsoleta, as normas do comércio internacional, aportadas pelo conduto dos que se faziam comerciantes no Brasil, atuavam com eficiência.

De mãos livres para planejar, instalar e explorar qualquer 
atividade, o indivíduo precisava ser dotado de sagacidade, tino; visão no ordenar, dirigir e executar, e habilidade no aproveitar o momento e prever as necessidades do futuro. Dêsse comportamento, ou melhor das usanças, práticas e técnica por êle gerados, embebeu-se o direito mercantil, que se fez sensivel às exigências da produção e do escambo, dando-lhes regulamentação flexível e adequada.

Corolário lógico da livre iniciativa econômica era a faculdade de variar de ramo de comércio ou indústria; ser ou deixar de ser industrial ou comerciante, se e quando quisesse. Dizia-se, por isso, e com inteira propriedade jurídica, decorrer de ato exclusivo de vontade o permanecer ou não à testa de emprêsa comercial.

Tais eram, a largos traços, os principios fundamentais do direito comercial pátrio. Direito privado por excelência, tinha os indivíduos $\mathrm{e}$ as entidades coletivas privadas como destinatários naturais de suas preceituações. Os organismos econômicos e os institutos foram criados e urdidos por essas pessoas e para elas, vindo a servir à riqueza geral.

5. - País de economia predominantemente agrária, nesta e nalgumas espécies minerais, tinhamos a base de nossa pauta de exportação. Pudéramos manter esta, com resultados mais ou menos favoráveis, enquanto nossos métodos obsoletos de produzir eram análogos aos seguidos pelas nacões concorrentes. Desde que estas, porém, começaram a evoluir para o sistema da grande produção, mercê de novas técnicas e novos processos, que propiciavam maior volume físico de utilidades, melhor qualidade e menor custo, fomos sendo paulatinamente eliminados dos mercados. Primeiro foi a borracha que entrou em crise, porque tentáramos valorizar artificialmente, a puro proveito dos intermediários e em detrimento do verdadeiro produtor, cuja penúria continuava a agravar-se. Conseqüência imediata foram as tentativas frustradas de ampará-la com medidas administrativas e financeiras, enquanto países que nos eram compradores, como a Inglaterra, entraram a cultivar a espécie nos seus domínios de além mar. Vem logo a seguir o café. Tínhamos perdido, em razão da primeira Guerra Mundial, o grande mercado próprio e de reexportação que fôra a Alemanha. Êste e muitos outros países da Europa, ou reduziram enormemente suas compras, ou as suspenderam de todo. Por outro lado, os Estados Unidos, que se torna, a partir de então, o nosso principal consumidor, retrai-se na procura, em virtude de várias causas, entre as quais se podem apontar a superproducão que não tinha como colocar-se e a grande crise bancária e bolsista.

Tenta-se acudir ao café, volvendo-se à política tìmidamente iniciada pelo Convênio de Taubaté. A pretêxto de proteger de iminente colapso a lavoura cafeeira, instituem-se medidas de inequívoco significado intervencionista. Força-se a valorização, seja através de taxas de sacrifício, seja pela limitação quantitativa e qualitativa das lavouras, seja ainda pela retenção ou destruição dos excedentes.

Resultado disso, foi que o preço alto, artificialmente criado, veio estimular outras nações a essa cultura. Em poucos anos, cada vez mais cresciam os nossos excedentes inexportáveis, pela concorrência que nos estavam fazendo os competidores, que indiretamente criáramos, enquanto os plantadores de casa estavam à beira da ruina completa. (4)

Também o cacau e o algodão entram a padecer do mesmo mal. Um, porque se retrai o comprador estrangeiro, outro, pela crise da indústria téxtil interna e pela concorrência da nova fibra, que São Paulo veio a produzir. Na esteira dêsses, outros produtos mais descendem em quantidade e preço, e vão reclamar providências administrativas análogas. Estas, via de regra emanadas de meros decretos do Executivo e, só de raro em raro, placitadas ou autorizadas por lei, embora já fôssem indícios do intervencionismo econômico que se avizinhava, conservam-se, entretanto, dentro de certa linha de prudência, deixando larga margem à iniciativa privada.

Eis que sobrevem a derrocada do sistema constitucional então vigente e se instaura outro, discricionário, no qual todos os poderes se enfeixam nas mãos do chefe do Govêrno. Fácil se tornou, a partir daí, a intervenção do público no privado.

6. - O prestígio de certas teorias, os precedentes da economia de guerra, adotados no exterior e em menor parte aqui, persuadiram alguns grupos de produtores de que sòmente os poderia salvar a intervenção governamental. Como na fábula das rãs, para ela voltam-se súplices, na esperança ilusória de que lhes devolveria a fartura perdida...

O Govêrno, de sua parte, cede a tão reiterados e instantes empenhos. Tinha já feito fortuna no direito administrativo a figura da autarquia. Era, pois, sòmente buscar nele a estrutura legal das novas instituições. Assim, surgem as autarquias econômicas, destinadas a regular a produção e o comércio, tais como - Departamento Nacional do Café, Instituto do Açúcar e do Alcool, Instituto Nacional do Mate, do Pinho, do Sal, etc. Autarquias de produção ou de realização de serviços, como o Lloyd Brasileiro, Navegação do Amazonas, Central do Brasil e outros.

(4) - Êsse grave êrro da nossa economia cafeeira, se aqui entre nós se fez
sentido, serviu também, para tema de estudo e ilustração de economistas sentido, serviu tambem, para tema de estudo e llustracãa de economistas 
Pelo critério burocrático, de que se não pode apartar, o poder público enche êsses organismos de um exército de funcionários. Insta angariar recursos com que remunerá-los. Para isso, ora acode o tesouro, ora suprem as próprias atividades produtoras sôbre que se faz sentir sua atuação. Dessarte, os encargos daquêles aumentam e estas últimas são gravadas com contribuições de tôda ordem, que se dissimulam sob o rótulo de taxas remuneradoras de serviços.

Todo sistema intervencionista, por mais brando que seja, observou mestre na matéria (5), pressupõe regulamentos. Êstes, por seu turno, carecem de funcionários que os façam cumpridos. Então, como a realidade dificilmente se ajusta à hipótese prevista naquêles, surgem as interpelacões e com estas os conflitos entre os agentes da fiscalização e os a ela sujeitos.

Ora, "o poder de regulamentar - observou o financista CULMANN - nos primeiros tempos de seu exercício, dá àquêles que o detém, quando falta-lhes adextramento anterior, uma espécie de entusiasmo ou exaltação. Exaltação de espírito e de vontade, embriaguez de mando, vontade criadora, tentação de criações originais: tantos quantos forem os móveis, tantas serão também as tentações de reduzir a difícil matéria humana, custe o que custar, a desenhos imagináveis e inacessíveis! Mas, se a vida resiste, será forçada; editar-se-ão ordenações sôbre ordenações e, por via de uma autoridade que se dispersa ao excesso, se quererá resolver os problemas que o simples jôgo das coisas, por si só, teria arranjado, com menos despesas".

7. - Sujeitos à fiscalização e ao contrôle dêsses vários departamentos, comércio e indústria foram perdendo a liberdade de movimentos. A circulação das riquezas já não poude fazer-se com a mesma facilidade, atentas as inúmeras formalidades de licença, visto, desembaraco de que ficaram a depender. Gravaram-lhes, ademais, taxas e contribuições; impuseramlhes papelórios e requerimentos do mais variado estilo, os quais, sôbre demandar tempo e gastos, ainda provocam freqüentes atritos entre particulares e agentes fiscalizadores.

Os projetos e planos sob que nasceram as autarquias destinadas a regular a produção e o comércio de certas utilidades, talvez teòricamente defensáveis, não se deram conta dos malefícios que iriam causar e vêm causando de maneira direta e reflexa. 'E' que, conforme doutrina o professor CAMILO VITERBO (6), “... seus efeitos reflexos se fazem sentir em regiões muito distantes daquelas nas quais a ação planificadora do Estado se produziu, de modo que

(5) - CULMANN - La Nouvelle Organisation Profissionnelle, pg. 121. não se deve alimentar ilusões demásiadas sôbre a possibilidade de limitá-la muito, quando ela se produza. As limitações são em geral só aparentes; sòmente acreditam nelas os que ignoram o caráter unitário e indivisível da economia do país. Desgraçadamente - conclui o publicista citado - a essa classe de ilusos pertencem muitos homens de govêrno, que tomam em consideração todos os efeitos que querem produzir com sua intervenção na economia e não se dão conta de que outros muitos, ainda que não queridos, se produzem, perturbando todo o sistema". (7)

Por isso mesmo, advertiu o professor GUSTAVO DEL VEC$\mathrm{CHIO}$ (8), catedrático de ciências econômicas na Universidade de Veneza, de quão difícil é coadunar os pressupostos teóricos da economia com a realidade objetiva desta. E' que, acentua êle, "não cabe à ciência econômica ensinar a um ministro o modo de comportar-se..."

Em faltas dessas incidiram muitas das medidas baixadas, em razão das quais ficaram afetados vários setores da produção e do comércio. Por via de conseqüência, a disciplina jurídica dessas atividades veio a ressentir-se profundamente. Os lembrados princípios clássicos de liberdade de produção e competição nos mercados sofreram restrições apreciáveis.

Não parou aí, porém, a marcha da economia dirigida.

8. - Proprietário de algumas emprêsas básicas, como por exemplo as de transporte ferrocarril, o Govêrno tivera o bom senso de dá-las em arrendamento a entidades privadas. Mas, o desgaste do material, que as tarifas progressivamente ina. tualizadas não permitiam sequer conservar, fizera os serviços piorar. Para melhorá-los instava reajustá-los na proporção das inversões a fazer. Era lógico advir daí aumento correspondente no preço dos serviços respectivos. Carregadores e passageiros teriam de o suportar. Insurgem-se êstes, porém, invocando por vêzes, inocentemente, argumentos tirados do sentimentalismo patriótico (9). A despeito disso, o Estado lhes deu guarida, abandonando, imperdoàvelmente, a linha justa.

Assim, não só retoma as emprêsas de seu domínio, como encampa outras mais, de propriedade particular. Pensa atender aos reclamos do maior número de interessados. Mas, notòria mente incapaz para ser empresário, não dá remédio ao mal, antes o agrava, tanto na qualidade do serviço, como no encarecimento dêste.

(7) - Cf. LERoY - BEAULIEU - Traité d'Economie Politique, 6a ed. v. II, pg. 20 (9) - Por serem essas emprêsas financiadas ou exploradas por entidades estran- 


$$
-60-
$$

Não satisfeito com isto e outros insucessos, o poder público se projeta em larga escala no campo do intervencionismo econômico. Torna-se possuidor e explorador de organismos produtores do mais variado quilate. Energia elétrica, comércio de seguros sôbre acidentes, bancos, emprêsas de transporte maritimo, ferrocarril de longa extensão e urbano, usinas siderúrgicas, fábrica de motores, artefatos bélicos, estaleiros navais, pertencem, hoje, ao Estado e são por êle explorados em regime de monopólio, ou em concorrência com os particulares.

Gozam essas autarquias ou sociedades de economia mixta de imensos privilégios. Imunidade fiscal, franquia telegráfica e postal, preferência para importacão em câmbio favorável e isenção de qualquer contrôle administrativo, estranho aos órgãos de que promanam, lhes dão situação singular no confronto e concorrência com as emprêsas particulares.

Compram e vendem pelo preço que entendem e pagam quando querem, pois não incorrem em quebra legal e o processo executivo, que se lhes intentasse, não teria o menor efeito.

Intervem o Estado na administração das entidades privadas, seja criando-lhes restrições aos negócios, à livre disponibilidade de bens e reservas, seja não lhes permitindo, mercê de uma mística de igualdade irreal, remunerar seus auxiliares pelo que êstes lhes mereçam. Impõe preços que se não ajustam às condições reais da oferta e da procura. Arbitra salários, sem levar em conta as verdadeiras possibilidades da produção. Força a "subscrição acionária e a tomada de títulos da divida pública, sem considerar as disponibilidades financeiras dos tomadores coactos. Nacionaliza empreendimentos vultuosos e proscreve a participação do capital alienígena, esquecido de que o capital pôsto a serviço da indústria segue a sorte desta. Limita a taxa de juros, sem suspeitar que vai oprimir as atividades produtoras e acoroçoar a agiotagem parasitária!

Onera a indústria e o comércio de pesados tributos, cuja arrecadação defeituosa e por vêzes vexatória, nem sempre tem aplicação condizente com a finalidade entrevista. Intervem nos contratos, ora para lhes suspender ou dilatar a exequibilidade, ora para impor ou derrogar cláusulas. Dá privilégios enormes ao Banco do Brasil, com lhe conferir, através da Superintendência da Moeda e do Crédito, a prerrogativa anômala de ditar aos outros bancos a taxa que hão de abonar aos seus depositantes, obrigálos a fazer depósitos compulsórios, com juro ínfimo, e grande parte sem juro algum; e, por fim, conceder ou negar-lhes licença para abertura de filiais e sucursais!. . .

9. - Em tôdas as épocas houve intervenção estatal na vida econômica. Variou apenas de extensão ou pro- fundidade, consoante circunstâncias políticas. Precedentes históricos não faltam, desde as leis de HAMMURABI até nossos dias. Sôbre que se questionou, porém, e ainda se questiona hoje, é acêrca do limite da intervenção. Esta, tanto pode ser desejável, benéfica e legítima, como indesejada, perniciosa e arbitrária. Tudo está em que os govêrnos atuem prudentemente, com os olhos fitos na realidade palpável, nas suas causas verdadeiras; que se atenham aos avisos da experiência e aos conselhos da ciência que, enfim, não planejem nem executem medidas dessa ordem sem considerar, prévia e maduramente, a extensão insuspeitada que poderão ter.

Foi sempre dever do Estado impulsionar a economia, tutelála, suprindo as deficiências da iniciativa particular ou coibindolhe os abusos. Mas, no em que exceder disso, sua ação periga transbordar para a malversacão e violência. Se reduz ou absorve as oportunidades que se poderiam legitimamente oferecer aos particulares, aniquila o espírito de iniciativa, de competição, de emulação pelo risco. Os empresários privados convertem-se, então, em funcionários públicos, em meros executores de ordens estaduais. $\mathrm{O}$ que isso significa de grave é fácil prever, já que, conforme acentuava LEROY-BEAULIEU (10), a experiência comprova que nem a designação pelos poderes públicos, nem a eleição popular, nem a escolha por corpos especializados podem assegurar um bom recrutamento de capacidade para êsses misteres. Sòmente, ao contrário, sob o regime de emprêsa livre e da direção por capitais privados da generalidade das operações e obras econômicas, é possivel formar-se a elite diretora.

De feito, adstritos às planificações administrativas, jungidos aos regulamentos, portarias, decisões do entorpecente mecanismo burocrático, os administradores das emprêsas produtoras perdem todo espírito de iniciativa e até mesmo o senso de responsabilidade. $\mathrm{O}$ marasmo, a indolência e o indiferentismo entram a dominar. Suas conseqüências são funestíssimas, e foram assim descritas pelo professor LUIS BAUDIN (11), analisando o problema em relação à Europa em geral e à França, em particular: "O enfraquecimento do espírito de iniciativa, a diminuição do gôsto pelo risco são sintomas certos do declínio de um povo. Foram os grandes aventureiros do pensamento e da ação, da ciência e dos negócios que deram ao nosso país sua riqueza e seu prestígio".

Tem sido justamente observado que a administração pública é orgânicamente inapta para gerir emprêsas econômicas. Mesmo aquêles serviços que lhe estão tradicionalmente reservados, porque o particular não os executaria, talvez, na medida e condições con-

(10) - Traité Théorique et Pratique d'Economie Politique, 6a ed. v. I, pg. 315.
(11) - Obr. cit. v. II, pg. 192 . 
venientes aos interêsses coletivos, mesmo nesses serviços, sua ação não é isenta de graves defeitos. Pecam pela irregularidade, quando não pelo alto custo. Ou então o preço unilateralmente imposto aos usuários está em manifesta desproporção com a capacidade econômica média dêstes. Por vêzes, ainda, a remuneração que se lhes exige é tão exígua que não cobre, sequer, as despesas com o pessoal.

Má qualidade, produção insuficiente e custo elevado são características quase constantes da obra econômica exercitada pelos poderes públicos.

As razões disso são inerentes ao órgão estatal, que é desprovido das aptidões requeridas para o mister e não tem a mais mínima possibilidade de as adquirir. Pelo contrário, quanto mais insiste, tanto mais se patenteia sua inópia, que se generaliza e agrava, contagiando seus servidores.

Sabe-se, com efeito, que a maior parte dos empreendimentos econômicos de estado são lançados nas épocas de crise, na vã esperança de a conjurar ou debelar. Mas, o de que se inadvertem os planejadores é que, sob a aparência de fenômenos tidos como exclusivamente econômicos, atuam, as mais das vêzes, outros fatores mais relevantes, que precisam ser perquiridos e eliminados, se se quiser medicação eficaz.

Aqui e alhures se podem colher exemplos sem conta. Já em 1908, por ocasião da chamada crise de superprodução, que tanto preocupou estadistas do velho mundo e induziu alguns a tentar resolvê-la a golpes legislativos, assim se pronunciou AFTALION: "Em lugar de nos atermos às manifestações exteriores dos fenômenos, é provàvelmente em nós, na alma humana, que é preciso procurar os fatores determinantes, as fôrças diretrizes. Assim como em outras matérias, a explicação é de ordem psicológica".

Em verdade, já houvera anteriormente notado TARDE, na sua "Psychologie Economique", a íntima correlação que há entre os fatores de ordem psicológica e certos fenômenos econômicos. $\mathrm{O}$ assêrto é, ainda agora, repetido pelos professôres PIETTRE LESCURE.

10. - Esquecido disso e com os vícios de base já assinalados, o político aventura-se a montar emprêsas produtoras, estruturadas não raro como as de iniciativa privada, mas destas diferindo radicalmente, seja pela ausência daquêles atributos possuidos pelo empresário particular, seja pela quase nenhuma responsabilidade que lhe toca, na eventualidade de insucesso.

Não levando em conta o mais mínimo cálculo de custo de produção, ou subestimando-o por exagerado otimismo, até porque os deficits podem ser fàcilmente cobertos, ou vão se acumulando de exercício para exercício, tais emprêsas têm, de ordinário, vida econômicamente vegetativa.

$\mathrm{O}$ espírito burocrático, que se apodera do pessoal a serviço de tais organizações, os inabilita para bem produzir.

$\mathrm{O}$ quadro desolador que vêm oferecer essas entidades econômicas públicas, no confronto com as da iniciativa privada, foi assim, magistralmente traçado pelo professor PIETTRE (12): "O indiferentismo, o automatismo, a rotina, a falta de dom de si mesmo, eis o que fará sempre a inferioridade da obra administrativa, comparada com a emprêsa privada - a menos que se opere uma transformação (não impossivel) da função pública, transformação assim profunda e no mesmo sentido da que se imporia para reformar a condição do proletariado e levar ao operário a alegria pelo trabalho e o prazer de criar".

Por tudo isso, fôra desejável que o Estado se abstivesse de intervir no campo econômico, ou que limitasse ao mínimo sua intervenção. Fala-se assim não por apêgo à mística da liberdade absoluta, ou especial preferência por êste ou aquêle sistema de economia. E' que, conforme diz RIPERT (13): “é fácil discutir sôbre o individual e o social, sôbre emprêsa e comunidade, sôbre dirigismo, nacionalização, sôbre financeiros e trustes. Mas, devemos recordar pontualmente que os meios de regulamentar a atividade dos homens são limitados, que as obrigações e sanções não se impõem fàcilmente, que há leis inaplicáveis e outras ina. plicadas, que as instituiçóes criadas pelo poder soberano podem ser deformadas ou suprimidas na prática".

11. - Em face das teorias e dos planos, dos projetos de reforma de conteúdo econômico, o jurista procura contribuir para que a imaginação de seus autores não os leve ao desencanto posterior, ou não os obstine a querer transformar $z$ dura realidade pelo modêlo de utópicas concepções. "A ciência jurídica - predicou RIPERT (14) — não admite nem doutrinas nem os partidários; estuda os fatos sem paixão, pois os considera ùnicamente em suas relações com o direito. Lança um julgamento severo sôbre as leis, mas tal julgamento não concerne senão à técnica das instituições e das regras; usa têrmos em que $o$ sentido é fixado por um longo passado e goza de uma experiência dos fatos humanos, adquirida e transmitida durante séculos".

Pode ela obtemperar, e aqui estão palavras do professor BRUNETTI (15): "O Estado tem por missão especial tutelar a

(12) 二 Economie Dirigée d'Hier et d'Aujourd'hui, pg. 195.
(13) A Aspectos Jurid. do Capitalismo Moderno, pg. 10.

(15) - Obr. cit. pg. 10. 
atividade privada, não absorvê-la ou deprimí-la, como aconteceria, vindo êle a exercer profissionalmente o comércio, o que o colocaria em tal posição de monopólio, opressiva da concorrência e perturbadora da economia geral. Um exercício de tal gênero não poderia adatar-se senão a um regime de socialização e estadualização das fôrças produtoras, como o soviético, no qual o Estado domina e dirige tôda a vida pública e privada, fazendo desaparecer a figura do comerciante privado".

Razão é esta por que, ante a progressiva invasão do poder público na órbita econômica, se tenha criado sério problema para o direito em geral e, designadamente, para o direito comercial. O fenômeno, que não é exclusivamente nosso, pois aqui se vem produzindo como decorrência de métodos e técnicas que importamos, tem chamado a atenção dos juristas de muitos países. No Congresso de Direito Comparado, que se realizou em 1948, na cidade de Montevidéu, assim falou o professor HAMEL (16), lente de direito comercial na Faculdade de Paris: "As relacóes do Direito Comercial com a economia dirigida constituem um problema muito grave do momento presente, que se põe, segundo creio, em tocios os países que lograram certo desenvolvimento econômico. Deixemos que os economistas e os políticos discutam sôbre a economia dirigida e apreciem suas vantagens e inconvenientes, sua oportunidade ou seus perigos. Nós outros, juristas, consideraremos a economia dirigida como um fato, que, bom ou mau, nos está imposto e vai repercutir sôbre nossas disciplinas próprias. O problema que se põe imediatamente para os juristas é, pois, o seguinte: não produzirá a economia dirigida o risco de fazer desaparecer as noções fundamentais de nosso Direito Comercial, ou, pelo menos, de introduzir em nosso Direito Comercial tradicional transformações muito graves? À medida que a economia dirigida vai estendendo-se e ganhando terreno, corremos o risco de que chegue a atacar os próprios fundamentos de nosso Direito Comercial; no meu entender - acentuava 0 comercialista francês - podemos considerar então que o desenvolvimento da economia dirigida planta, no campo do Direito $\mathrm{Co}_{0}$ mercial, o mais grave problema que se apresenta atualmente à consideração do jurista".

12. - Realmente, a nacionalização de certas atividades produtoras implica restrições à iniciativa privada, à livre emprêsa. Representa, portanto, a negação parcial, ao menos, de um dos postulados sôbre que se erigiu o direito mercantil. $\mathrm{O}$ regular a produção e o comércio, qual fazem as diversas autar* quias já mencionadas, é, sem dúvida, atacar a liberdade, outro grande princípio do direito comercial. Conferir a autarquias ou sociedades de economia mixta, votadas à produção de serviços ou utilidades, franquias, isenções e privilégios, significa, igualmente, oprimir ou sufocar a livre concorrência, ou, mais precisamente, fazer concorrência desleal. Envolve isto alteração profunda do conceito e dos princípios elaborados pela doutrina comercialista sôbre os extremos da competição lícita.

De igual modo, o número sempre cada vez maior de emprêsas econômicas de estado, organizadas e estruturadas nos mol des das de propriedade privada, inclusive sob bases comerciais de rendimento ou lucro, como se verifica até mesmo na Rússia soviética (17), faz pensar se não será caso de alterar-se o conceito tradicional de comerciante, para compreender nele o Estado empresário.

Todos êsses fatos vêm produzindo fortes repercussões na órbita do direito mercantil, e já têm ensejado pronunciamentos os mais diversos.

Querem uns que essa ativa participação do poder público no meneio dos negócios acabe por esvaziar de conteúdo o direito comercial, que virá a ser absorvido pelo direito público. Propendem outros por que venha a ser o direito administrativo, ao qual cabe reivindicar a disciplina total das atividades exercidas pela pública administração, que recolherá a herança deixada pelo extinto direito comercial.

Objetam alguns mais que nem uma nem outra das precedentes solucões se conforma com a boa técnica e lógica científica. Diz-se, então, que, se o direito comercial se revela agora insuficiente para atender as novas e vitais exigências da moderna economia, o remédio não seria forçá-las a entrar em nenhum dos quadros precedentes, mas sim estruturar-se um direito novo. Seria êste o direito econômico.

Não faltaram vozes conspícuas que evidenciaram o exagêro das doutrinas, lembrando que, se é fato notório a progressiva participação do Estado na vida do tráfico, êste fato, longe de denunciar o iminente desaparecimento do direito comercial, pode bem traduzir, quiçá, a futura comercialização do direito público. E' que, e são palavras do professor GARRIGUES (18), catedrático da Universidade de Madrid: ". . . Por ora, ùnicamente se pode afirmar que, embora enquadrado no marco de uma economia dirigida e subordinada a limitacões de interêsse público preferente, $o$ ato jurídico individual sobrevive a tôdas as mudanças 
legislativas, dotando o ordenamento jurídico mercantil de uma resistência vital, que faz pensar, não já na absorção pelo direito administrativo, mas, ao contrário, na comercialização do direito público".

Em verdade, êsse fenômeno pode bem advertir-se na Rússia soviética, onde as emprêsas do Estado são planificadas e estrutu radas nos moldes da economia capitalista e têm sua disciplina jurídica no código civil e comercial daquêle país.

13. - Parece, portanto, prematuro, falar no iminente desaparecimento do direito comercial. Os novos fatos e relações estarão, por certo, a aconselhar uma revisão de princípios e conceitos, como ainda há pouco sugeriu o professor VAN RYN (19) da Universidade Livre de Bruxelas, no concurso de conferências ali realizado. Mas, se isso é labor de futuro, iá agora pode o jurista, como ensina o professor HAMEL, exigir que as pessoas de direito público tenham comportamento condizente com a nova situação. Se o Estado se converte em indus trial, transportador, segurador, banqueiro, deve atuar como atuaria o comerciante, o particular. Os juristas do direito comercia - preleciona o mestre parisiense - devem ser estritamente rígidos neste ponto: devem limitar a intromissão do direito público no direito privado, exigindo que o Estado, ao converter-se em comerciante, banqueiro e segurador, se conduza exatamente como um comerciante privado, um banqueiro privado ou segurador privado. Do contrário, as conseqüências seriam muito graves: graves, em primeiro lugar, do ponto de vista da emprêsa regida pelo Estado, que correria sem dúvida o risco de ter funestos resultados (20); graves, também, pelo que se refere à liberdade e independência dos cidadãos que, no terreno econômico comercial, não devem ser objeto de diferenciacõos que não surjam diretamente da própria vida comercial". (21)

(19) - Revue Trimestrelle de Droit Commercial, 1953, pgs. 565 e segts. com graves danos para o erário público e, em última analise, para a
fortuna particular, de onde são tirados os recursos para o financiamento

(21) - Os estabelecimentos montados pelo poder público para o exercício do comércio, a pretêxto de promover o barateamento do preço de utilidade de consumo necessário, fazem concorrência desleal aos negociantes par
ticulares, mercê dos favores de que desfrutam e, não raro, bem minguados são os resultados que apresentam.

\section{A INSEMINAÇÃO ARTIFICIAL EM FACE DA MORAL E DO DIREITO}

\author{
ARMANDO DIAS DE AZEVEDO \\ Catedrático de Direito Civil
}

\begin{abstract}
1. Posição do problema. - 2. Na escala animal. 3. O problema na espécie humana. - 4. Opiniões de escritores. - 5. Opiniões de juristas. -6 . Distinções e conceitos. - 7. A inseminação artificial própria e os moralistas. - 8. A inseminação artificial imprópria e os moralistas. - 9. A palavra de Pio XII aos médicos. - 10. A palavra de Pio XII às parteiras. - 11. A palavra de Pio XII aos membros de um Congresso Científico. - 12. Opiniões dos protestantes. - 13. Outras advertências contra a hétero-inseminação. - 14. A inseminação artifical humana e os regimes totalitários. - 15. - A inseminação homóloga e o direito. - 16. A inseminação heteróloga e o direito. - 17. No campo do direito de família. - 18. Revisão dos textos legais vigentes de direito civil. - 19. A adoção como remédio legal. - 20. Hétero-inseminação e adultério. - 21. Héteroinseminação e injúria grave. - 22. A inseminação artificial e o estupro. - 23. Revisão do Código Penal. - 24. Responsabilidade dos médicos. - 25. Conclusões.
\end{abstract}

1. Por demais chocantes são os contrastes que nos oferece a época tormentosa que atravessamos, com o espetáculo da humanidade, ébria de tecnicismo à outrance (1), impregnada de materialismo, desorientada pelo amoralismo, idólatra do cientificismo. 